\title{
WATER GATE DYNAMICS AS INFLUENCED BY PARAMETERS OF HYDRAULIC TURBINE SPEED GOVERNORS AND CONTROLLERS
}

\author{
M. Z. El-Sadek \\ Electrical Engineering Department, Faculty of Engineering, \\ Assiut, Egypt \\ Gaber Shabib \\ Electrical Engineering Department, High Institute of Energy, \\ Aswan, Egypt \\ Email: gabershabib@yahoo.com

\section{Wael M. Soliman} \\ High Dam Power Station, Hydro Power Generation Company, \\ Aswan, Egypt
}

(Received July 16, 2006 Accepted July 29, 2006)

\begin{abstract}
The paper investigates the effect of hydraulic turbine speed governor parameters on water gates dynamics of the hydraulic turbines. These parameters are water starting time, temporary speed droop, transient time and permanent speed droop. This is done in order to improve the performance of the hydraulic turbine speed governor in power systems and to reduce water gate oscillations. This paper also investigates the application of the conventional and fuzzy logic controller based on the hydraulic turbine speed governor on water gate dynamics. Nonlinear simulations are performed in a 3 machine power system show that influences.
\end{abstract}

\section{INTRODUCTION}

In the middle of twentieth century, considerable attention has been directed towards the problem of improving the design of turbine governors, because of its influence on the dynamic performance of hydro and steam power plants. Several authors have investigated the hydraulic turbine speed governor, and effects of its parameters on stability of power systems, whereas the system is a single machine with infinite bus. Other authors have investigated the optimum adjustment of hydro governors [1, 2, 3]. Until recently, analog devices have dominated the scene of generating unit controllers. Digital governors opened the door for implementing more complex algorithms due to their flexibility. As a result, the speed loop started interfering with the excitation loop, so that mutual interaction of these control loops provided possibilities for obtaining better transients and wider stability margins. Water gates dynamics are not sufficiently studied in literature although they form an important element in hydraulic power plants operation $[4,5]$. 
In addition, there has been considerable interest in the application of intelligence control techniques to design nonlinear controllers for modern large interconnected power systems. The objective is to extend the operational margins of stability to enhance transient stability [6,7]. Recent development in intelligence control theory and digital technology shows that substantial improvements may be achieved using such advanced techniques. The intelligent control is introduced in power system studies to overcome inherent complexities and uncertainties that are always present in a variety of forms. Influence of such controls on water gates dynamics has not received sufficient attention [8].

In this paper, developed fuzzy logic gate controllers are applied to a 9 - bus three machine power system which is used in system simulation. Each machine of the multimachine power system is provided with a fuzzy controller in its governor controller loop. Each controller employed local variables only. The proposed controllers are shown to have excellent performance. The results of the water gates dynamics are demonstrated by computer simulation studies and compared with the turbine speed governor without controller and with conventional controller.

\section{HYDRAULIC TURBINE AND ITS SPEED GOVERNOR COMPONENTS}

The hydraulic turbine speed governor is shown in Fig. 1:

Where: $\mathrm{g}$ gate position, $\sigma$ is permanent speed droop coefficient, $\delta$ transient speed droop coefficient, $T_{W}$ water starting time, $T_{R}$ dashpot time, $T_{S}$ servotime constant [9], $\mathrm{U}_{\mathrm{c}}$ is output of conventional controller and $\mathrm{U}_{\mathrm{g}}$ is output of fuzzy controller.

The turbine governor dynamics are described by the following set of equations:

$$
\begin{aligned}
& \dot{\mathrm{g}}=-\frac{1}{\mathrm{~T}_{\mathrm{S}}}\left(\omega-\omega_{\text {ref }}+\alpha+\sigma \mathrm{g}\right) \\
& \dot{\alpha}=-\frac{\delta}{\mathrm{T}_{\mathrm{S}}}\left(\omega-\omega_{\text {ref }}+\alpha+\sigma \mathrm{g}\right)-\frac{1}{\mathrm{~T}_{\mathrm{R}}} \alpha \\
& \dot{\omega}=\frac{1}{2 \mathrm{H}}\left(\mathrm{P}_{\mathrm{m}}-\mathrm{P}_{\mathrm{e}}-\mathrm{P}_{\mathrm{L}}-\mathrm{D} \omega\right)
\end{aligned}
$$

\section{TURBINE SPEED GOVERNOR WITH CONVENTIONAL CONTROLLER}

Turbine speed governor with conventional controller is used to enhance damping of the electric power system oscillations. In this paper, the transfer function of the conventional controller is given in the following form [12]:

$$
\mathrm{G}(\mathrm{s})=\frac{\mathrm{K} \mathrm{s}}{1+\mathrm{T}_{1} \mathrm{~s}}\left[\frac{1+\mathrm{T}_{2} \mathrm{~s}}{1+\mathrm{T}_{3} \mathrm{~s}}\right]^{2}
$$

Where; the first factor on the right of equation (4) is a reset factor that is used to washout the compensating effect after a time $T_{1}$ with stabilizer gain $\mathrm{K}$. And the second 
factor is lead - lag compensator with time constants $T_{2}$ and $T_{3}$, respectively. The input to conventional controller is the speed signal $\Delta \omega$ and the output $\mathrm{U}_{\mathrm{c}}$ is injected at the input sumner of the speed governor as shown in Fig. 1.

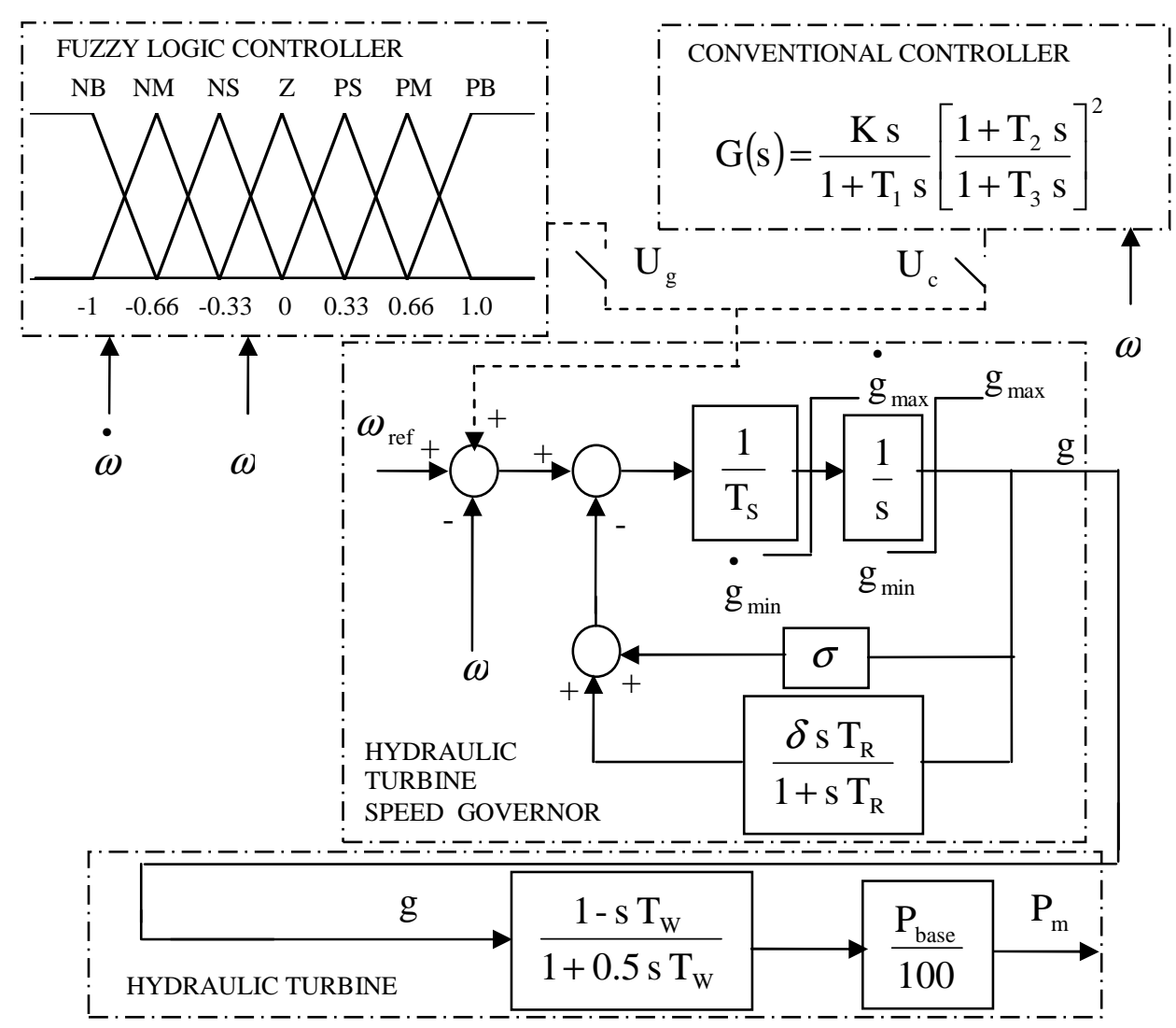

Fig. 1: Hydraulic turbine speed governor.

\section{FUZZY LOGIC CONTROLLER FOR HYDRAULIC TURBINE SPEED GOVERNOR}

The application of fuzzy logic controller for controlling the multimachine power system through their hydraulic turbine speed governing system are well documented $[13,14]$. The proposed fuzzy logic governor controller has two inputs speed deviation $\Delta \omega_{\mathrm{j}}$ and acceleration $\Delta \omega_{\mathrm{j}}$ selected for machine \# $\mathrm{j}$ in a multimachine power system. This proposed controller has a single output control signal $\mathrm{U}_{\mathrm{g}}$, which is applied to the summing point of the governor loop to produce damping of the electromechanical oscillations after disturbances. This improves the transient and dynamic performance of the water gate position. Figure $\mathbf{1}$ shows a mechanical hydraulic speed governor for hydraulic turbine with fuzzy logic controller. 


\section{WATER GATE DYNAMICS SIMULATION STUDIES}

The water gate position is the output of the hydraulic turbine speed governor. Simulation studies are presented first to examine the gate dynamics in presence of turbine speed governor without controller when its parameters are variant. Also, time simulations have been performed on the nonlinear system with the proposed control technique. The IEEE 9 - bus multimachine power system shown in Figure 2 is used for the simulation. The studied system consists of one hydro-machine and two steammachines, which are mutually coupled. Each of those three generators is equipped with turbine speed governor and exciter provided with AVR. The parameters of all generators, governors, exciters, AVR, transmission lines, loads and operating conditions are given in reference [15]. All generators are equipped with the proposed fuzzy controller. In addition, all generators are equipped with conventional controller and without controller for comparison purposes.

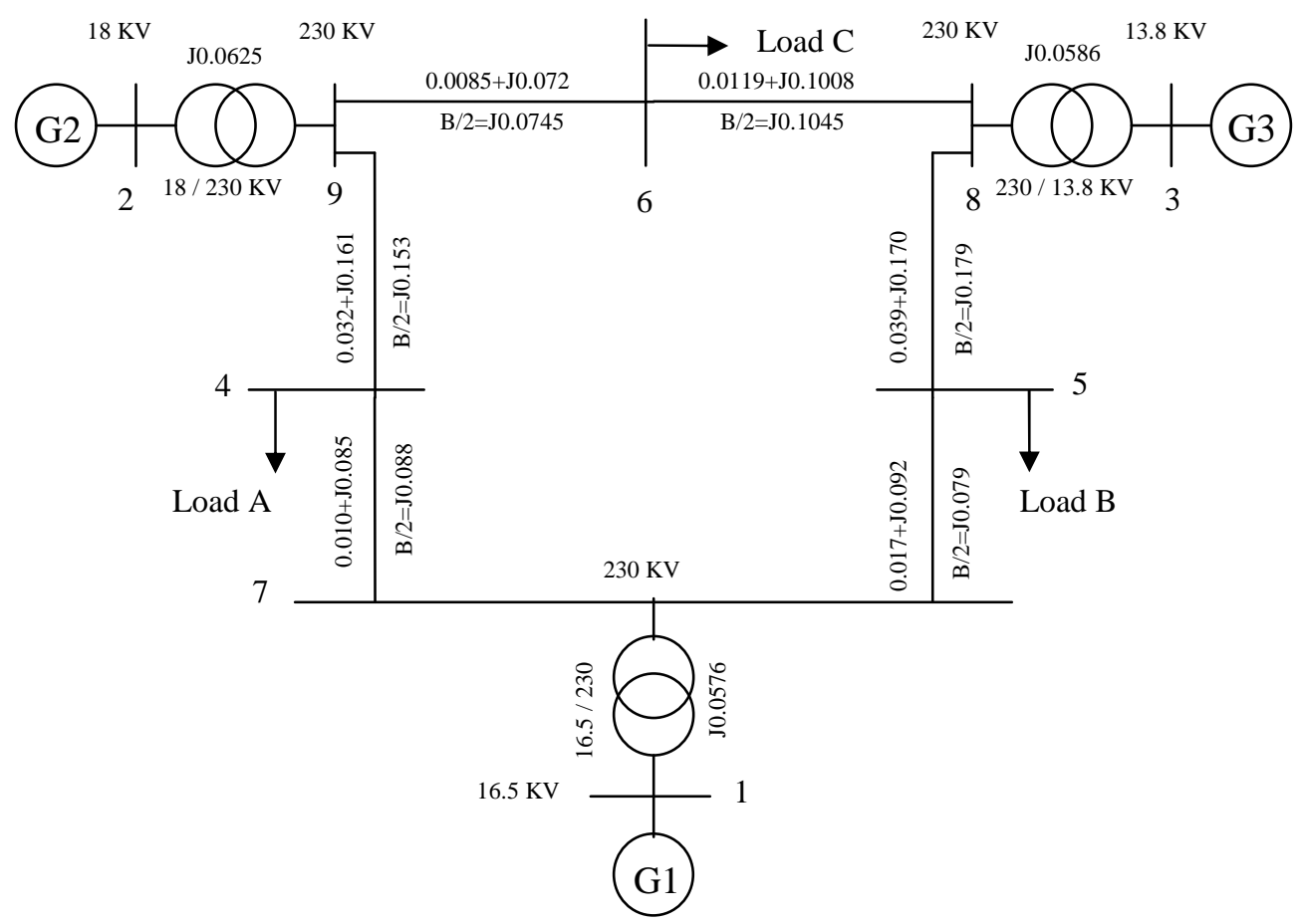

Fig. 2: Multimachine power system.

The multimachine power system is subjected to a disturbance in order to observe system dynamics as affected by speed governor control parameters and types. A three phase short circuit at bus number 9 is applied for $100 \mathrm{~ms}$ at $\mathrm{t}=1 \mathrm{sec}$. with successful reclosure. 


\section{Case 1: Water Gate Dynamics as Influenced by Speed Governor Parameters:}

\section{a) Influence of Water Starting Time $T_{w}$ on Water Gate Dynamics:}

Figure 3 (i, ii, iii) shows the time responses of the mechanical power, gate position and the speed deviation respectively after applying the disturbance. In practice, the length of the penstock and area are constant and $h_{\text {base }}$ is small changeable overall day, so any change in $\mathrm{T}_{\mathrm{W}}$ is strongly related to change in flow rate; whereas the flow rate is dependent on the gate. So, figure $\mathbf{3}$ (i, ii, iii) shows that, if water starting time is large, the turbine produce a high discharge with less power than when the water starting time is small at the same head.

(i)

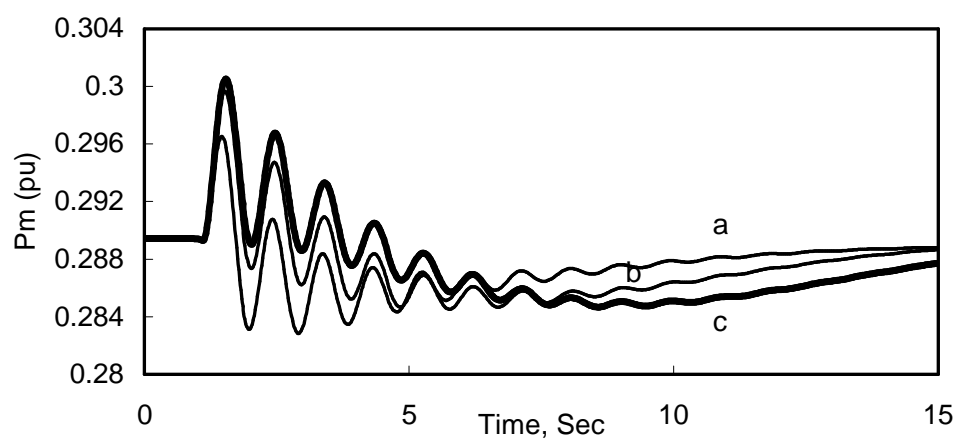

(ii)

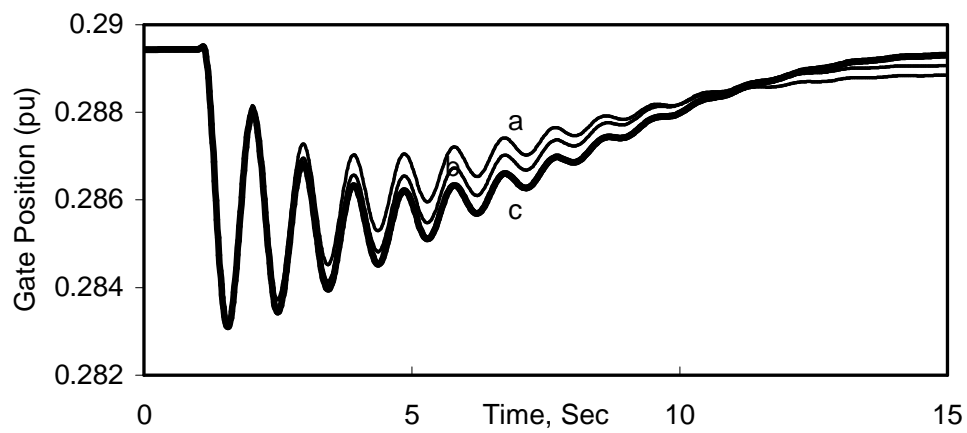

(iii)

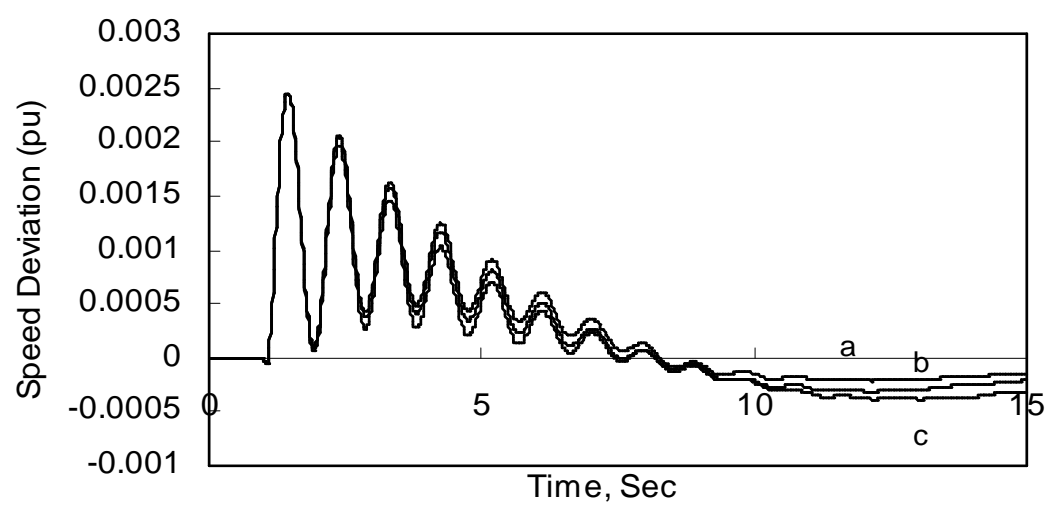

Fig. 3: Time responses for different water starting time
a) $T_{W}=1$,
b) $T_{W}=3$,
c) $T_{W}=5$. 


\section{b) Influence of Temporary Speed Droop $\delta$ on Water Gate Dynamics:}

Figure 4 (i, ii, iii) shows the time responses of mechanical power, gate position as well as speed deviation after applying the disturbance with various values of $\delta$. Three values are adopted $\delta=0.3,0.6$ and 1.0. When the temporary speed droop $\delta$ is large, the gate oscillations and mechanical power is less than when the temporary speed droop $\delta$ is small. This large transient regulation is required because of the response characteristic of the hydraulic turbine to sudden changes in control gate position in conjunction with the inherent system load damping [16].

(i)

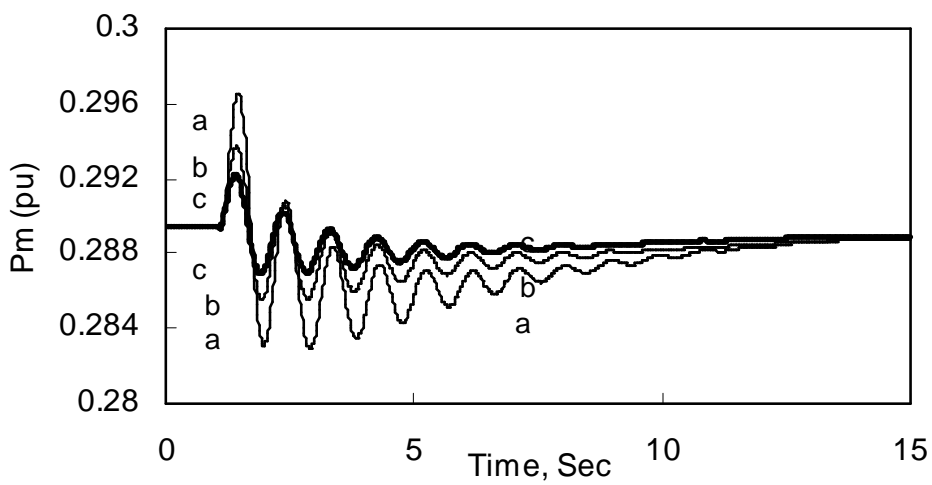

(ii)

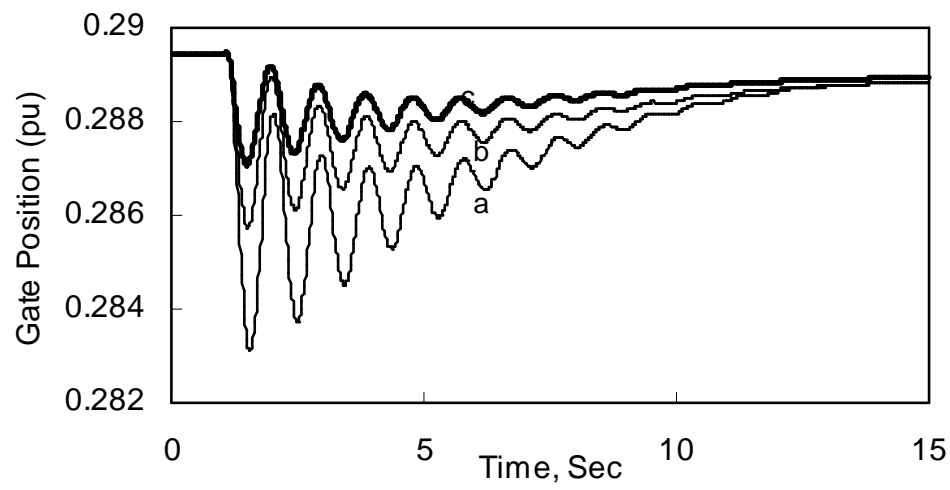

(iii)

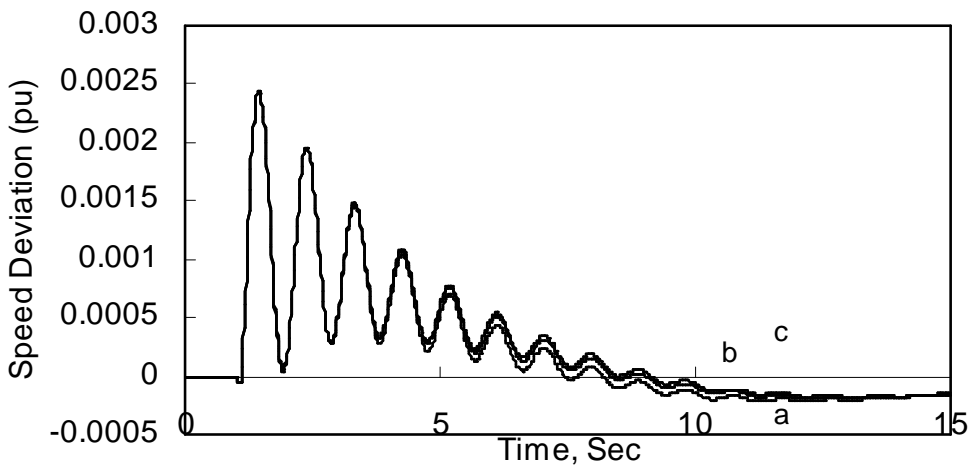

Fig. 4: Time responses for different temporary speed droop
a) $\delta=0.3$,
b) $\delta=0.6$,
c) $\delta=1.0$ 


\section{c) Influence of Transient Time $T_{R}$ on Water Gate Dynamics:}

Figure 5 (i, ii, iii) shows the time responses of mechanical power, gate position and speed deviation with three values of $\mathrm{T}_{\mathrm{R}}=5,15$ and 25 and after applying the disturbance.

(i)

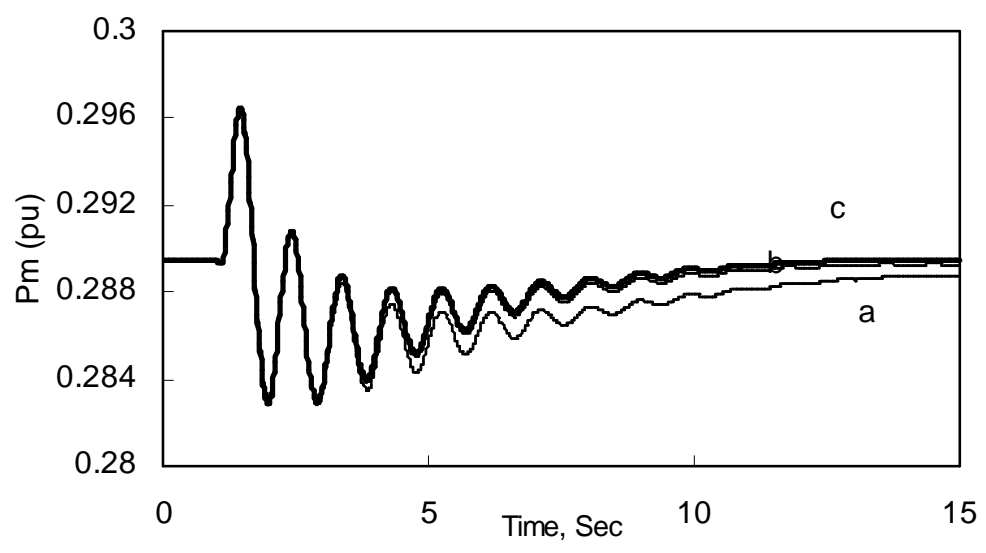

(ii)
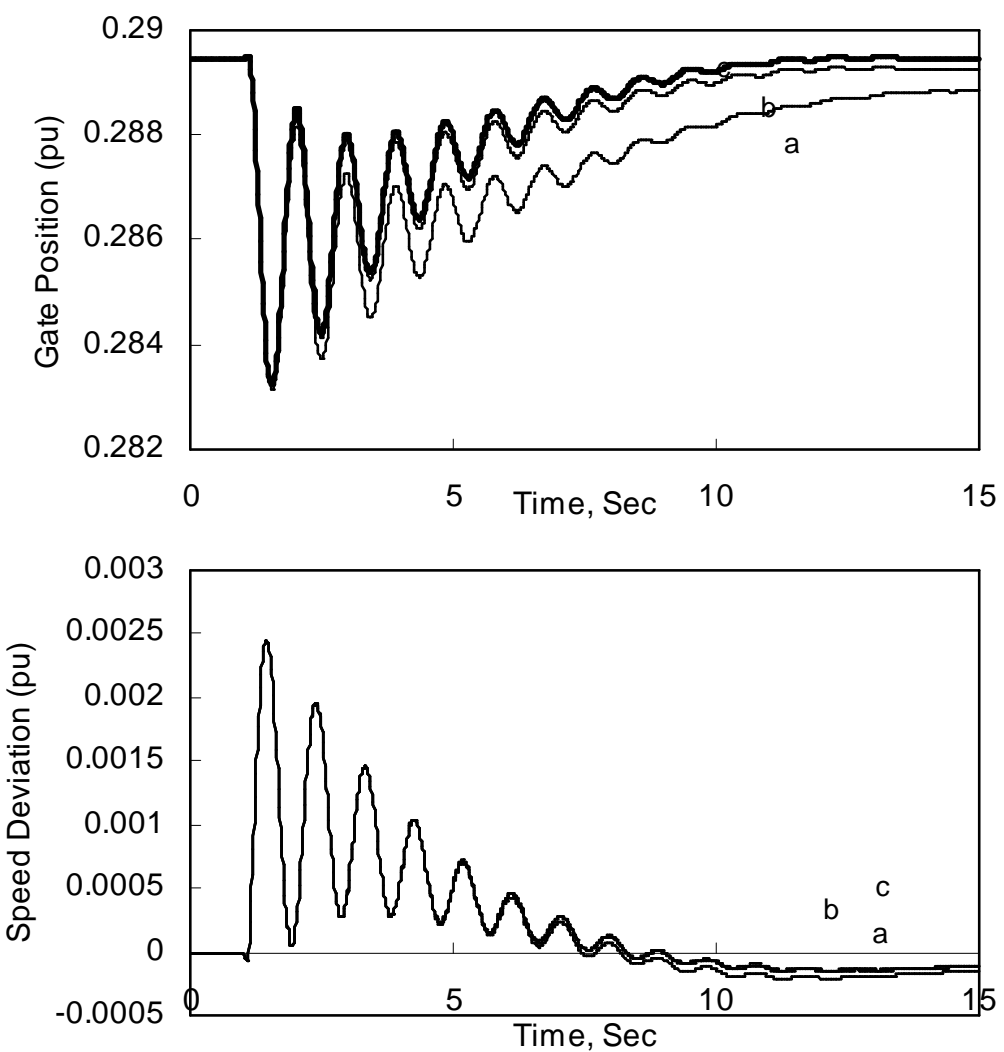

Fig. 5: Time responses for different transient time
a) $T_{R}=5$,
b) $T_{R}=15$,
c) $T_{R}=25$ 


\section{d) Influence of Permanent Speed Droop $\sigma$ on Water Gate Dynamics:}

Figure 6 (i, ii, iii) shows the time response of the mechanical power, gate position and the speed deviation when various values of permanent speed droops $\sigma$ are used and after disturbance application. Three values of $\sigma$ are $0.02,0.05$ and 0.06 . From this figure we conclude that the broad regulation improves stability. Reference [16] proved that the optimum permanent speed droop $\sigma$ values are 0.04 and 0,05 . These values lead to better system stability.

(i)
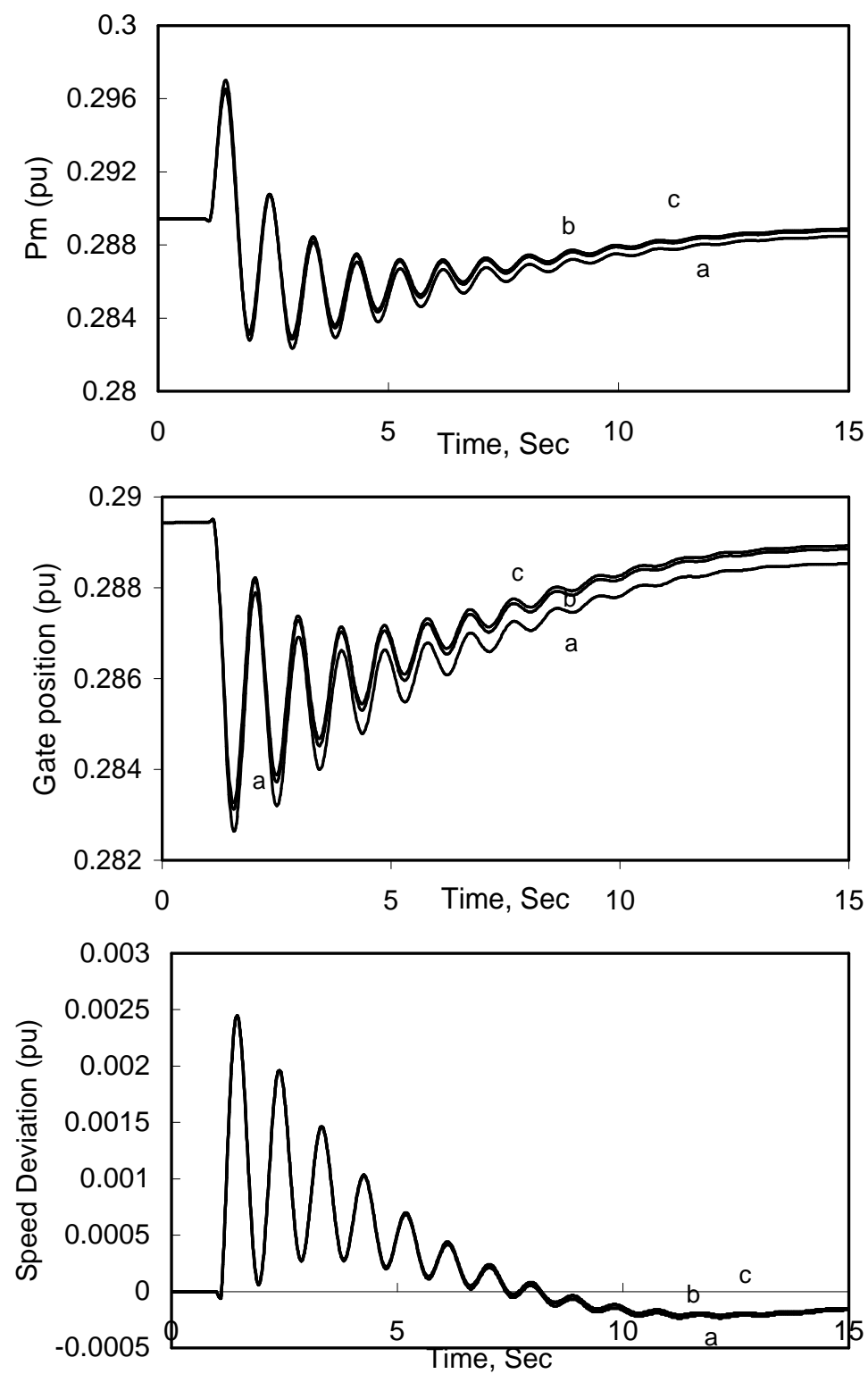

Fig. 6: Time responses for different permanent speed droop
a) $\sigma=0.02$,
b) $\sigma=0.05$,
c) $\sigma=0.06$ 


\section{Case 2: Water Gate Dynamics as Influenced by Hydraulic Turbine Speed Governor Controlled by fuzzy logic control signals:}

Figure 7 (i), (ii) shows the responses when unit 1 only is equipped with a fuzzy logic controller and when it is equipped with a conventional controller. The figures show the time responses of the hydraulic turbine gate position and the hydraulic turbine speed deviation in case of the fuzzy logic controller with the hydraulic turbine speed governor loop only. The figures demonstrate that gate response is similar to that of a single machine - infinite bus system [17]. Figure 8 (i, ii) shows the time responses of the hydraulic turbine gate position and hydraulic turbine speed deviation in case of the fuzzy logic controller on the three turbine speed governors.

It can be seen from the previous figures that the fuzzy logic controller presents a good performance. By comparing responses corresponding to the fuzzy controller with turbine speed governor, without controller, and with conventional controller, it can be seen that the system transient performance under large disturbances, is highly improved. The improvement is due to the addition of large amount of positive damping to the summing point of turbine speed governor control loop. Water gate oscillations are well damped upon using such fuzzy logic control signals at the input of the hydraulic turbines speed governors.

(i)

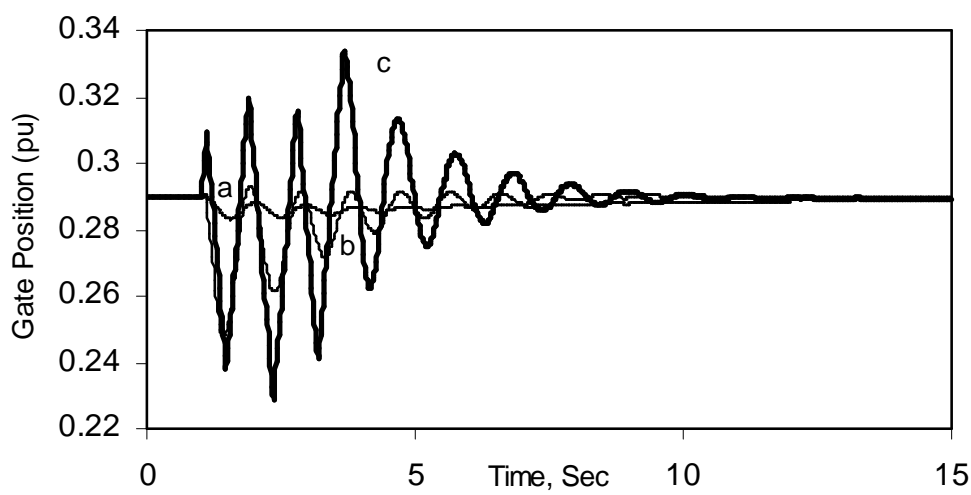

(ii)

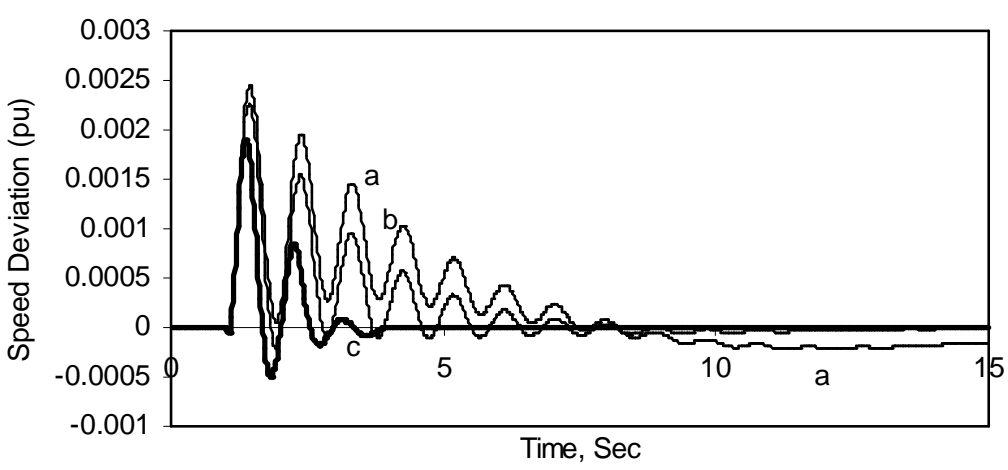

Fig. 7: Time responses for three phase short circuit of $100 \mathrm{~ms}$.

a) Turbine speed governor without controller

b) Turbine speed governor with conventional controller on M/C 1 only

c) Turbine speed governor with Fuzzy logic controller with M/C 1 only 
(i)
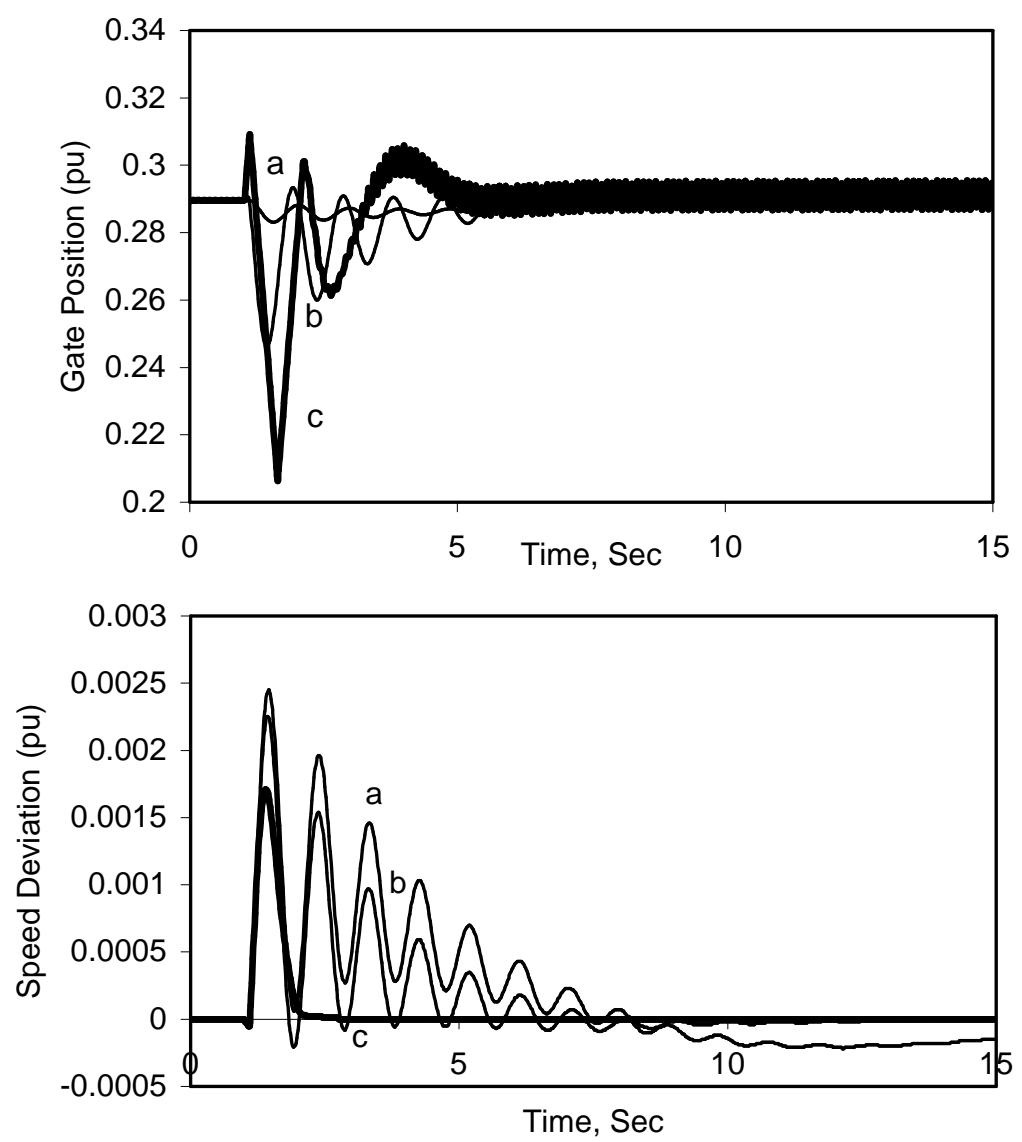

Fig. 8: Time responses for three phase short circuit of $100 \mathrm{~ms}$

a) Turbine speed governor without controller

b) Turbine speed governor with conventional controller with three units

c) Turbine speed governor with Fuzzy logic controller with three units

The following performance indices are considered in this paper to evaluate the previous controller

$$
\mathrm{J}_{\omega \mathrm{j}}=\sum_{\mathrm{k}=1}^{\mathrm{N}}\left(\Delta \omega_{\mathrm{j}}(\mathrm{k})\right)^{2}
$$

Where; $\Delta \omega(\mathrm{k})$ is the speed deviation of the machine $\mathrm{j}, \mathrm{N}$ number of samples. Figure 9 and Figure 10 show the results for the system in case of speed governor without controller, conventional speed governor controller and fuzzy logic controller with unit 1 only and fuzzy logic controller with the three units. Decrease of performance index indicates better damping and more stability of the system. 


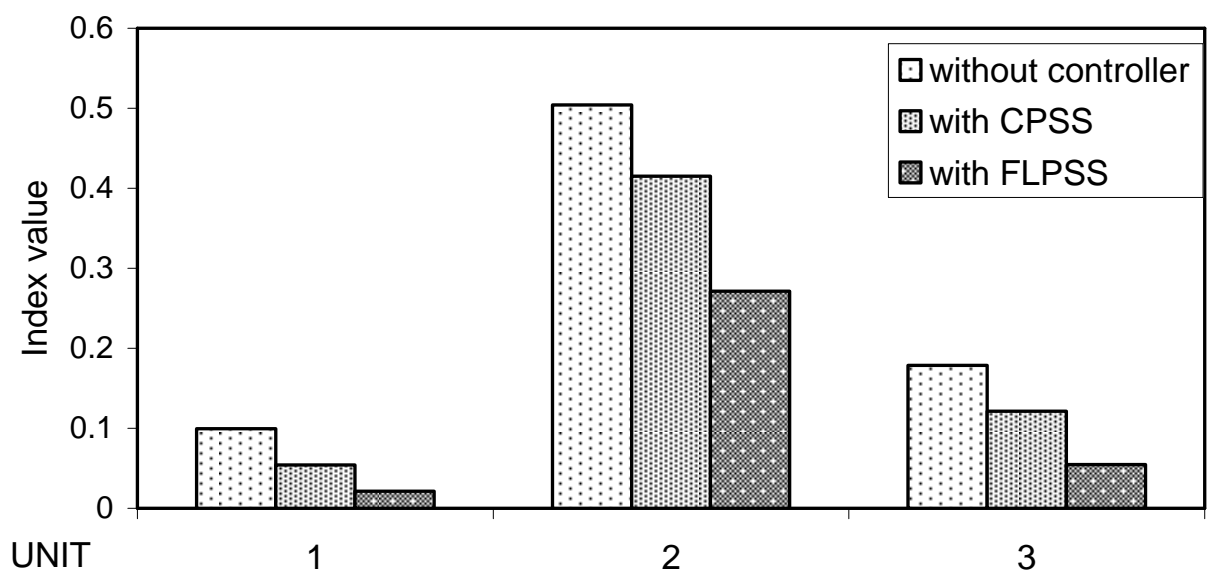

Fig. 9: Performance index value in the case of controller on M/C 1 only.

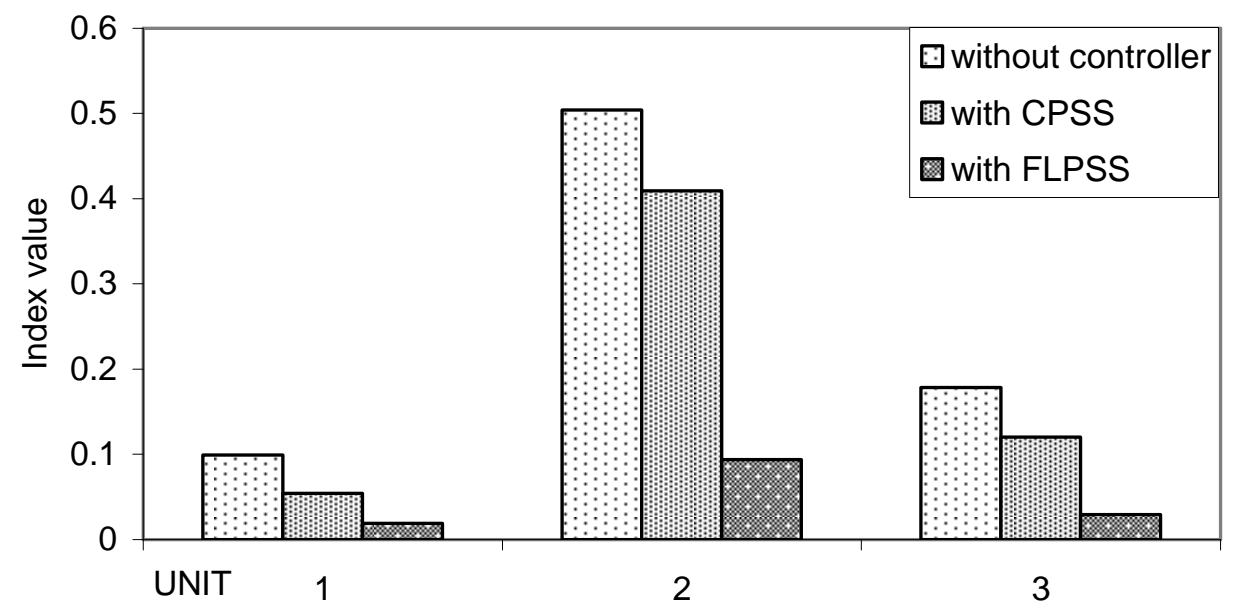

Fig. 10: Performance index value in the case of controllers on all machines.

\section{CONCLUSIONS}

From this study we conclude the following:

1. If water-starting time is large, the turbine produces a high discharge with less power than when the water starting time is small at the same head.

2. When the temporary speed droop is large, the gate oscillations are less than when the temporary speed droop is small. This large transient regulation is required because of the response characteristic of the hydraulic turbine to sudden changes in control gate position.

3. Fuzzy logic controller offers a good performance. By comparing responses corresponding to the fuzzy controller with turbine speed governor without controller and with conventional controller, it can be seen that the system transient performance under large disturbances, is highly improved. 
4. The digital simulation results prove the effectiveness of the fuzzy controller over governor open loop on water gate oscillations during the disturbance.

\section{REFERENCES}

[1] N. G. Dennis, 'Water Turbine Governors', Mechanical Engineers, Vol.7, Nov.1952.

[2] Georg Hutarew, 'Tests on turbine governing systems', Water turbine, pp. 157 164, April1963.

[3] L. M. Hovey, 'Optimum Adjustment of Hydro Governors on Manitoba Hydro System', AIEE Trans., Vol.8, pp. 581 - 587, Dec. 1962.

[4] S. Younis, 'Speed Control of Hydroturbine Using Personal Computer', M. Sc., High Institute of Energy, Aswan, Egypt 2001.

[5] Y. A. Mubarak, 'A Study of Power System Automatic Generation Control Using MATLAB and SIMULINK Programs', Cairo University, Ph.D, degree admission, 2003.

[6] Ragaey . A.F. Saleh, 'Genetic Algorithm Tuned Fuzzy Logic Based Governor Controller for a Fully Superconducting Generator', MEPCON'2003, Minoufiya University, Shebin EL - Kom, Egypt 2003, pp. 125 - 130.

[7] M. Mahmoud, K. Dutton and M. Denman,' Design and Simulation of a Nonlinear Fuzzy Controller for a Hydropower Plant', Electric Power Systems Research Journal, Elsevier, Vol.73, issue 2, pp. 87 - 99, 2005.

[8] M. Z. EL - Sadek, 'Power Systems Control', Book, Muchtar Press, Assiut, Egypt, 2004.

[9] Working group on prime mover and energy supply models for system dynamic performance studies, 'Hydraulic Turbine and Turbine Control Models for Dynamic Studies', IEEE Trans. on PES, Vol.7, No.1, Feb. 1992, pp. 167 - 179.

[10] P. Kundur, 'Power System and Control', McGraw Hill Book Company, New York 1994.

[11] F. R. Schleif and A. B. Wilbar, 'The Coordination Of Hydraulic Turbine Governors For Power System Operation', IEEE Trans. Vol. PAS 85, pp. 750 758, July 1966.

[12] Li - Xin Wang, 'A Course in Fuzzy Systems and Control', Book, Prentice Hall PTR, 1997.

[13] R. Podmore, 'Power System Dynamic Simulation Program - Used Manual', Department Of Electrical Engineering. University Of Saskatchewan, Jan. 1974.

[14] M. Z. EL - Sadek, G. Shabib, W. M. Soliman, 'Transient Stability Enhancement Using Artificial Intelligence Based Fuzzy Governor Controller', Journal of Engineering Sciences, Assiut University, Vol. 34, No. 3, pp. 923 - 936, May 2006.

[15] P. M. Anderson and A. A. Fouad, 'Power System Control and Stability', Book, $2^{\text {th }}$ IEEE Press, USA 2003. 
[16] A. B. Gamal, M. Z. EL - Sadek, Y. A. Mubarak, 'Applicable Values of Turbines Speed Governor Regulation', MEPCON'2005, Port Said, Egypt 2005, pp. 39 42.

[17] Djordj M. Dobrijevic and Marko V. Jankovic, 'An Approach to the Damping of Local Modes of Oscillations Resulting from Large Hydraulic Transients', IEEE Trans. on EC, Vol.14,No.3, Sept. 1999, pp. $754-759$.

\section{تأثير بارامترات منظمات سرعة التربينة الهيدروليكية علي ديناميكية بوابات الماء}

هذه المقالة تبحث تأثنير بـار امتر ات منظمـات سـر عة التربينـة الهيدروليكية علي ديناميكيـة

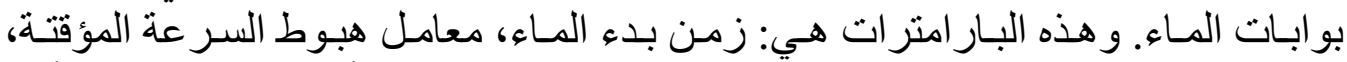

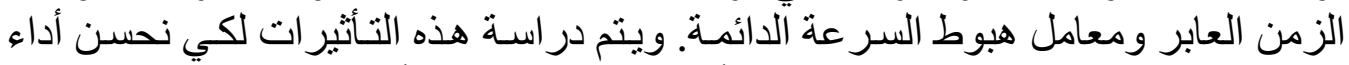

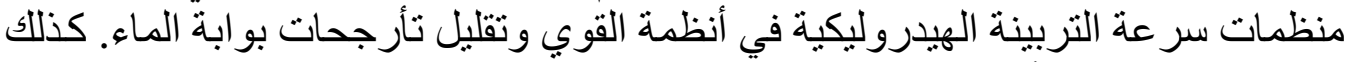

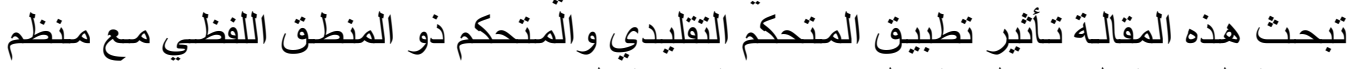
سر عة التربينة الهيدروليكية علي ديناميكية بو ابة الماء. 